\title{
Stratigraphy and glaciotectonic structures of permafrost deformed beneath the northwest margin of the Laurentide ice sheet, Tuktoyaktuk Coastlands, Canada
}

\author{
Julian B. MURTON, ${ }^{1}$ Righard I. WALleR, ${ }^{2}$ Jane K. HART, ${ }^{3}$ Colin A. WHiteman, ${ }^{4}$ \\ WAYNE H. POLLARD, ${ }^{5}$ IAN D. CLARK ${ }^{6}$ \\ ${ }^{1}$ Department of Geography, University of Sussex, Brighton BN1 9Q7, England \\ E-mail:j.b.murton@sussex.ac.uk \\ ${ }^{2}$ School of Earth Sciences and Geography, Keele University, Keele, Staffordshire ST5 5BG, England \\ ${ }^{3}$ School of Geography, University of Southampton, Highfield, Southampton SO17 1BJ, England \\ ${ }^{4}$ School of the Environment, University of Brighton, Brighton BN2 4GJ, England \\ ${ }^{5}$ Department of Geography, McGill University, 805 Sherbrooke Street West, Montreal, Québec H3A 2K6, Canada \\ ${ }^{6}$ Department of Earth Sciences, University of Ottawa, 140 Louis Pasteur, Ottawa, Ontario K1N 6N5, Canada
}

\begin{abstract}
The upper 5-20 m of ice-rich permafrost at three sites overridden by the northwest margin of the Laurentide ice sheet in the Tuktoyaktuk Coastlands, western Arctic Canada, comprise massive ice beneath ice-rich diamicton or sandy silt. The diamicton and silt contain (1) truncated ice blocks up to $15 \mathrm{~m}$ long, (2) sand lenses and layers, (3) ice veins dipping at $20-30^{\circ}$, (4) ice lenses adjacent and parallel to sedimentary contacts, and (5) ice wedges. The massive ice is interpreted as intrasedimental or buried basal glacier ice, and the diamicton and silt as glacitectonite that has never thawed. Deformation of frozen ground was mainly ductile in character. Deformation was accompanied by sub-marginal erosion of permafrost, which formed an angular unconformity along the top of the massive ice and supplied ice clasts and sand bodies to the overlying glacitectonite. After deformation and erosion ceased, postglacial segregated ice and icewedge ice developed within the deformed permafrost.
\end{abstract}

\section{INTRODUCTION}

An opportunity to examine glacier-bed interactions beneath cold-based ice is provided by field investigations of Pleistocene permafrost in formerly glaciated regions. Previous work in such regions has provided evidence for glacier-ice thrusting near the northwest limit of the Laurentide ice sheet (LIS) (Mathews and Mackay, 1960; Mackay and others, 1972), and for a deformable bed of permafrost beneath the southern Kara ice sheet (Astakhov and others, 1996). Observations of the stratigraphy and structural geology of near-surface, glacially deformed permafrost provide basic information about the rheology of sub-marginal permafrost, and thus are essential for modelling and reconstructing ice sheets with cold-based margins. Because recent numerical models suggest that subglacial permafrost was probably more extensive than previously assumed (Cutler and others, 2000), acquiring information about its former existence is of vital importance.

The aim of this paper is two-fold: (l) to examine the evidence for glacier-permafrost interactions beneath the northwest margin of the LIS, and (2) to infer the rheological conditions during sub-marginal deformation of permafrost. To this end, the paper describes the stratigraphy and glaciotectonic structures in the upper $\sim 5-20 \mathrm{~m}$ of permafrost at three sites in the Tuktoyaktuk Coastlands, western Arctic Canada (Fig. 1). The paper focuses on permafrost that is ice-rich, because glacially deformed ground ice within the stratigraphic sequences indicates that the ground has not thawed since the time of deformation.

\section{PERMAFROST AND GLAGIAL HISTORY}

The Tuktoyaktuk Coastlands form that part of the Arctic Coastal Plain between the Mackenzie Delta and Amundsen Gulf, Northwest Territories (Fig. 1; Rampton, 1988a). They are in the zone of continuous permafrost, the maximum thickness of which is $\sim 750 \mathrm{~m}$ beneath northeast Richards Island (Judge and others, 1987; Taylor and others, 1996).

Glacier ice of the northwest sector of the LIS overrode most of the Tuktoyaktuk Coastlands during the Toker Point Stade. The age of the Toker Point Stade is disputed: an earlyWisconsin ( $>35 \mathrm{kyr} \mathrm{BP})$ age has been inferred from regional Quaternary mapping (Fig. 1; Rampton, 1982, 1988a; cf. Vincent, 1992), whereas a mid- or late-Wisconsin age has been suggested from studies of aeolian and glaciofluvial deposits ( $<35$ kyr BP; Dallimore and others, 1997; Murton and others, 1997). The ice flowlines and glacial limits reconstructed by Rampton (1982, 1988a) are shown in Figure 1. One major ice lobe flowed north-northwestward along the Mackenzie Valley, before fanning out northwest across the Yukon Coastal Plain and northeast across Richards Island and the southwest end of the Tuktoyaktuk Peninsula (Fig. 1). Another large ice lobe, in the vicinity of the Kugaluk and Anderson Rivers, flowed northward and then north-north- 


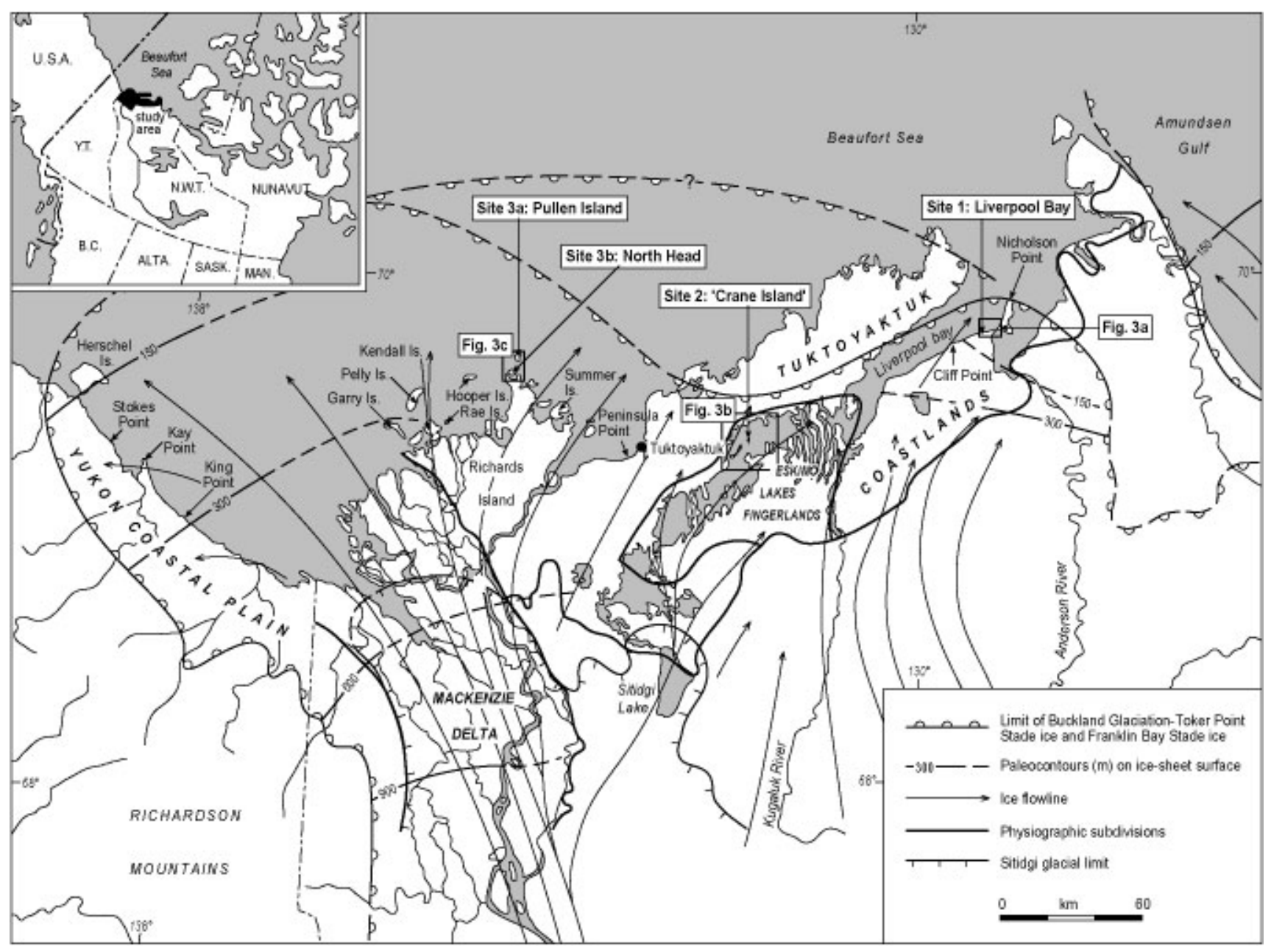

Fig. 1. Location map of the Tuktoyaktuk Coastlands and Yukon Coastal Plain. Ice-flow directions and ice limits of the Toker Point Stade and Sitidgi Stade are according to Rampton (1988a).

eastward towards Nicholson Point. The interior of the Mackenzie Valley lobe is inferred to have been warm-based from the occurrence of eskers, drumlins, extensive spreads of ice-marginal glaciofluvial sediments and the reconstructed low glacier profile (Beget, 1987; Rampton, 1988a). The western and eastern margins of these lobes have been placed by Rampton (1982, 1988a) near ice-thrust elevated ground at Herschel Island and at Nicholson Point, respectively (Fig. 1). Buried glacier ice from the LIS has been identified on Richards Island, Summer Island, Herschel Island and in the Eskimo Lakes Fingerlands (Fig. 1; Dallimore and Wolfe, 1988; Rampton, 1988a; French and Harry, 1990; Pollard, 1990; Murton and others, in press).

Permafrost existed in the Tuktoyaktuk Coastlands and the Yukon Coastal Plain prior to the last Laurentide glaciation. Its existence is inferred from glacially-folded and faulted icy layers reported by Mackay and others (1972) at Herschel Island, Stokes Point, Kay Point, King Point, Garry Island, Pelly Island, Hooper Island, Kendall Island, Rae Island, Richards Island, near Tuktoyaktuk and at Nicholson Point (Fig. 1). This deformation has been attributed to glacier-ice thrusting (Mackay and others, 1972) and appears similar in nature to the deformation discussed in this paper.

\section{METHODS}

Stratigraphic sections $\sim 5-20 \mathrm{~m}$ high and $\sim 20-300 \mathrm{~m}$ long were logged sedimentologically and sketched in order to determine the stratigraphy of the deformed permafrost. Descriptions of ice and sediment facies follow those of Murton and French (1994).

Clast fabrics were measured in three samples of diamicton and one sample of underlying massive ice in order to (1) compare them with fabrics reported from basal glacier ice (Lawson, 1979a; Ham and Mickelson, 1994; Bennett and others, 1999), and (2) assess if the diamicton and massive ice displayed similar strain signatures. The orientation and dip of at least 30 clasts with $a: b$ axis ratios of $\geq 3: 2$ were measured and plotted on Schmidt equal-area stereonets. From these data were calculated the three principal eigenvalues ( $S_{1}, S_{2}$ and $S_{3}$; Mark, 1973), as well as fabric isotropy $\left(I=S_{3} / S_{1}\right)$ and fabric elongation $\left(E=1-\left(S_{2} / S_{1}\right)\right)$ (Benn, 1994).

Petrographic analysis of one sample of massive ice from Pullen Island (Fig. 1) was carried out in order to determine the characteristics of the ice crystals and sediment inclusions, and the crystal $c$-axis orientations. The analyses were carried out in the McGill University Geocryology Laboratory, following methods described by Langway (1958). The sample block was trimmed and cut into thick slices to facilitate examination of cryogenic structure and inclusion patterns. Vertical thin sections were prepared from subsamples of the block sample and examined under cross-polarized light to determine crystal size and shape, and plane light to examine structural characteristics. Crystal $c$-axis orientations were measured using a standard Rigsby stage. The 


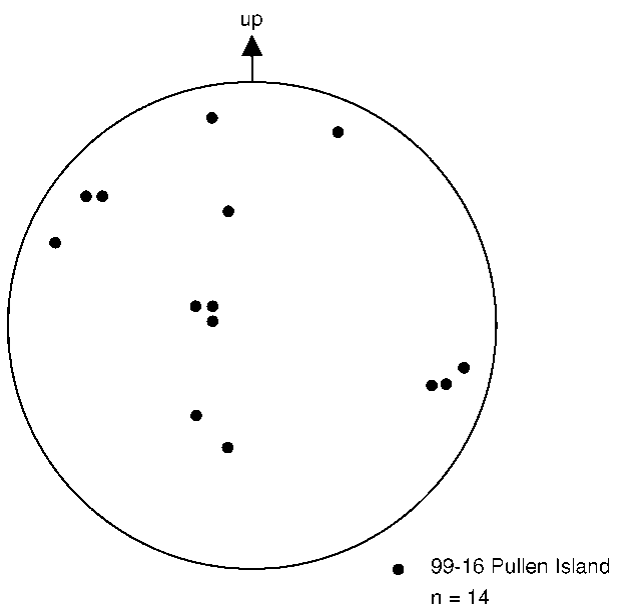

Fig. 2. Lower-hemisphere projection of c-axis orientations on a Schmidt net of a vertical thin section of massive ice from Pullen Island.

high sediment content made thin-section and systematic $c$ axis orientation problematic. Approximate fabric patterns were obtained by partially melting and refreezing oriented chip samples and were plotted as lower-hemisphere projections on a Schmidt equal-area net (see Fig. 2).

Oxygen and deuterium isotopic analysis of ground ice within permafrost was undertaken in order to (l) determine the water source for the ice and the conditions of freezing, and (2) test the hypothesis that blocks of ice dispersed within diamicton derive from underlying massive ice and are therefore isotopically similar. The analyses were carried out in the G. G. Hatch Stable Isotope Laboratories,
University of Ottawa, to an analytical precision of $\pm 1 \%$ o for $\delta \mathrm{D}$ and $\pm 0.1 \%$ of or $\delta^{18} \mathrm{O}$.

\section{OBSERVATIONS}

The stratigraphy of ice-rich permafrost in glaciated terrain of the Tuktoyaktuk Coastlands is described below from three sites that provide large vertical sections through terrain veneered by Toker Point till (Rampton, 1988a, map 1647A) and that contain abundant deformation structures and ground ice. Site 1 is on the southern shore of Liverpool Bay, extending from the mainland directly southwest of Nicholson Island for $\sim 5 \mathrm{~km}$ to the west (Figs 1 and $3 \mathrm{a}$ ). Site 2 is located on northern 'Crane Island' (informal name), in the central Eskimo Lakes (Figs 1 and 3b). Site $3 \mathrm{a}$ is on western Pullen Island (Figs 1 and 3c), and site $3 \mathrm{~b}$ is on the northwest bluff of an adjacent island at North Head (Figs 1 and $3 \mathrm{c}$ ).

The permafrost stratigraphy of these sites comprises massive ice beneath ice-rich diamicton or sandy silt. The massive ice is at least $\sim 2.5-8.0 \mathrm{~m}$ thick, and either (i) white and bubble-rich, or (ii) grey, debris-rich and banded. Its upper contact is a planar to irregular angular unconformity. The overlying diamicton and sandy silt is $\geq 4$ to $\sim 12 \mathrm{~m}$ thick, and contains (1) ice blocks, many of which have internal debris bands that are truncated along block margins; (2) sand lenses and layers, some of which show boudinage and some that contain recumbent, isoclinal and Zshaped folds; (3) ice veins that are aligned and dipping at $20-30^{\circ}$; (4) ice lenses adjacent and parallel to sedimentary contacts; and (5) ice wedges. The stratigraphy, sedimentology, deformation structures, ice petrography and stable
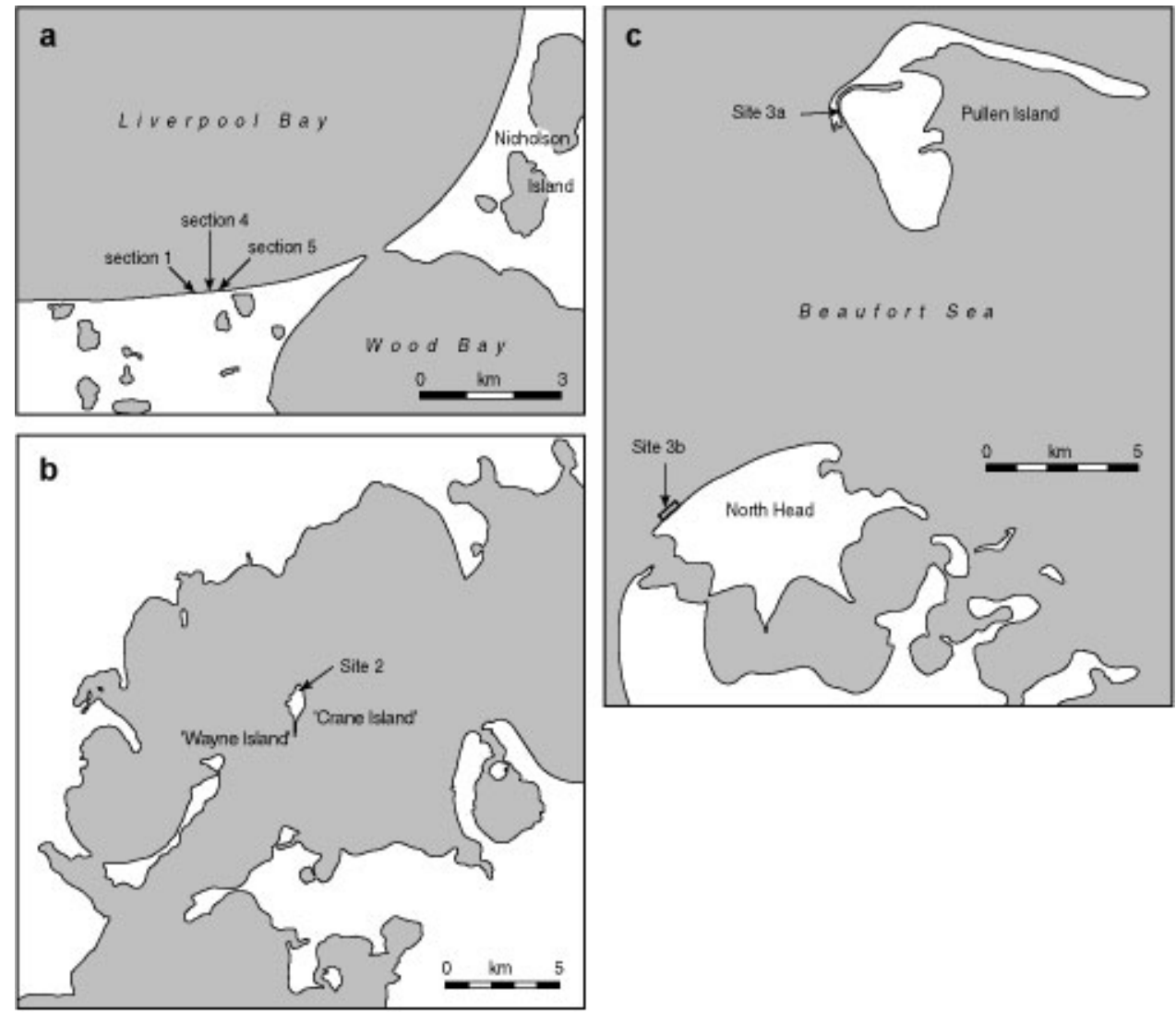

Fig. 3. Location of sites at (a) Liverpool Bay; (b) 'Crane Island', central Eskimo Lakes; and (c) Pullen Island and North Head. Locations are shown in Figure 1. 
Table 1. Stratigraphy and glaciotectonic structures of near-surface permafrost at site 1, Liverpool Bay

\begin{tabular}{lll}
\hline Stratigraphic unit & Description & Structures
\end{tabular}

Ice-rich diamicton Matrix of tenacious sandy-silty clay to silty sand; ( $\geq 4 \mathrm{~m}$ thick) very dark grey (7.5YR 3/0 wet); structureless; matrix-supported; rounded to subangular pebbles and cobbles; clast-fabric isotropy $=0.058$ and 0.084 , elongation $=0.871$ and 0.829 (Fig. $6 \mathrm{a}$ and $\mathrm{b}$ ) Three subunits identified in section 5 (Fig. 5e):

(3) upper stony diamicton ( $\sim 0.5 \mathrm{~m}$ thick) with angular to rounded cobbles and pebbles

(2) central clayey diamicton ( l m thick)

(1) lower sandy diamicton ( $\sim 4 \mathrm{~m}$ thick)

Gryostructure mainly reticulate; crustal cryostructure (segregated ice) around some rock clasts; several large ice lenses $(\leq 0.2 \mathrm{~m}$ thick and $\leq 5 \mathrm{~m}$ long), distinguished from the ice blocks by their elongate shape and tapered ends, observed within or directly above sand lenses in the diamicton; reticulate ice within the diamicton has $\delta^{18} \mathrm{O}$ value of $-29.4 \%$
Massive ice 2 types of ice:

( $\sim 3$ to $\geq 8 \mathrm{~m}$ thick) (1) White, bubble-rich ice (at least $3 \mathrm{~m}$ thick) contains few layers of sand-poor ice and ice-rich sand (few $\mathrm{mm}$ to $\sim 40 \mathrm{~cm}$ thick); lower contact sharp and gently undulating to irregular, more or less parallel to ice lens $2-3 \mathrm{~cm}$ thick, containing vertical tubular bubbles, located a few centimetres below the contact, in Kittigazuit Formation sand; mean $\delta^{18} \mathrm{O}$ value $=-32.5 \%$, std dev. $=0.5 \%, n=5$ (Fig. $7 \mathrm{a})$

(2) Dark grey, banded ice (bands few $\mathrm{mm}$ to $\sim 40 \mathrm{~cm}$ thick): intercalated pure ice (bubblerich to bubble-free), aggregate-poor ice, sandpoor ice and ice-rich sand; aggregate-poor ice contains dispersed diamicton with sandy silty clay matrix and granules to pebbles; single $\delta^{18} \mathrm{O}$ value of $-31.4 \%$

In some sections (2) overlies (1) (Fig. 5c); in others, (1) forms prominent layers within (2) (Fig. 5e). Upper contacts of types (1) and (2) sharp and gently undulating to irregular, truncating bands in type (2) at low angle (angular unconformity). Arching of upper contact to within $\sim 1 \mathrm{~m}$ of the ground surface where overburden is thinnest $(\sim 1 \mathrm{~m})$

Kittigazuit Fine- to medium-grained brown sand (Rampton, Formation 1988a); contains numerous ice veins; lens of segre( $\geq 2 \mathrm{~m}$ thick) gated ice $(2-3 \mathrm{~cm}$ thick $)$ a few $\mathrm{cm}$ below upper contact has $\delta^{18} \mathrm{O}$ value of $-32.2 \%$
Lenses and layers $(\sim 0.1-50 \mathrm{~cm}$ thick, $\sim 0.03-$ $30 \mathrm{~m}$ or more long), horizontal to sub-horizontal, of (1) brown, fine sand; (2) grey, fine sand; and (3) pebbly sand; some lenses and layers show boudinage, and some contain recumbent isoclinal and Z-shaped folds with axial planes generally sub-horizontal

Ice blocks (Fig. 8), mostly rounded to subrounded, with sharp margins; long axes commonly $10-50 \mathrm{~cm}$, horizontal or dipping at a few degrees to west; short axes commonly 5$25 \mathrm{~cm}$; largest block $\sim 15 \mathrm{~m}$ long and $\sim 1.5 \mathrm{~m}$ high (Fig. $8 \mathrm{~b}$ ) is visually indistinguishable from the underlying, banded massive ice; some blocks streamlined, some folded and a few contain folds truncated along block margins (Fig. 8a); ice facies comprise variable array of (a) clear, pure ice; (b) aggregate-poor ice; (c) sand-poor ice; (d) sand-rich ice; and (e) ice-rich sand; ice generally banded; bands commonly truncated along one or more sides of blocks; $\delta^{18} \mathrm{O}$ values of -26.9 and $-28 \%$ o

Ice veins commonly a few $\mathrm{mm}$ thick, $20-60 \mathrm{~cm}$ high and spaced 3-10 $\mathrm{cm}$ apart in diamicton and a sand lens; veins dip at $\sim 20^{\circ}$ to east; similar veins observed within a sand lens

Folds (isoclinal recumbent) common in banded massive ice

Cracks, horizontal to gently dipping, common in white, bubbly massive ice

\section{Glacitectonite}

Ice lenses (segregated ice) post-date deformation

Brown sand above upper stony subunit (3) probably derived from Kittigazuit Formation

Intrasedimental, segregated, intrusive or segregated-intrusive ice (type 1); cracks are shear planes

Regelation ice (type 2) associated with shearing and melting along upper contact of type 1 ice

Erosional upper contact of banded ice

Arching of upper contact attributed to unloading (cf. Mackay and Dallimore, 1992)
Preglacial aeolian sand containing intrasedimental ice isotopes for each site are listed in Tables $1-3$ and illustrated in Figures 2 and 4-11.

\section{INTERPRETATION}

In order to evaluate the evidence for glacially deformed permafrost, we must first consider the origin of the massive ice, because this comprises a major element of the exposed stratigraphy and a potential source of ice blocks within the overlying sediments. Secondly, we discuss the evidence for subglacial deformation and erosion. Finally, we interpret the features associated with postglacial processes.

\section{Origin of massive ice}

The white, bubble-rich massive ice at Liverpool Bay probably formed within pre-existing sediment (i.e. 


\begin{tabular}{lll}
\hline Stratigraphic unit $\quad$ Description & Structures
\end{tabular}

Ice-rich silt Silt-rich; abundant masses of peat and undulat-

$(1.5-2.5 \mathrm{~m}$ thick $)$ ing, ice lenses $(\leq \sim 0.2 \mathrm{~m}$ thick; $\leq \sim 5 \mathrm{~m}$ long); ice wedges extend down from base of modern active layer

Ice-rich

diamicton

( $\sim 5 \mathrm{~m}$ thick $)$

Very dark grey; silty clay matrix; massive to faintly laminated; matrix-supported; abundant pebble- to cobble-size rock clasts, some striated and/or faceted; clast-fabric isotropy $=0.185$, elongation $=0.532$ (Fig. $6 \mathrm{~d}$ ); contains buried ice wedges with tops at $2-3 \mathrm{~m}$ depth; reticulate ice has mean $\delta^{18} \mathrm{O}$ value of $-31.0 \%$, std dev. $=0.3 \%$ $(n=3)$

Massive ice Bands (1-25 cm thick) of (1) aggregate-poor ice (at least $2.5 \mathrm{~m}$ with dispersed pebbles and cobbles, (2) ice-rich thick) medium to coarse sand (or pebbly sand), (3) sand-rich ice and (4) sand-poor ice; clast-fabric isotropy $=0.074$, elongation $=0.894$ (Fig. 6c); upper contact sharp, irregular $(\leq 3 \mathrm{~m}$ relief), truncating bands in massive ice; $\delta^{18} \mathrm{O}$ values of -29.4 and $-29.9 \%$
Postglacial colluvium
Lamination, horizontal to sub-horizontal, parallel to lower contact

Ice blocks $(\leq 0.7 \times 0.3 \mathrm{~m})$

Tight to isoclinal folds with horizontal to gently dipping axial planes
Glacitectonite

Tops of deeply buried ice wedges mark base of early-Holocene active layer (thaw unconformity)
Buried basal ice beneath erosion surface

Sand represents glaciofluvial outwash

Table 3. Stratigraphy and glaciotectonic structures of near-surface permafrost at site 3a, Pullen Island

Stratigraphic unit Description $\quad$ Structures

Sandy silt $\quad$ Very dark grey (7.5YR 3/0) sandy silt and dark $(\sim 12 \mathrm{~m}$ thick $) \quad$ greyish brown $(2.5 \mathrm{Y} 4 / 2)$ fine sand; few dispersed pebbles to cobbles, commonly rounded to subrounded; several ice lenses $(\leq 5 \mathrm{~cm}$ thick and $70 \mathrm{~cm}$ long), horizontal, just above top of underlying massive ice, aligned parallel to it, with $\delta^{18} \mathrm{O}$ value of $-28.6 \%$

Massive ice $(\geq 4$ m thick $)$

Bands (typically $\sim 3-10 \mathrm{~cm}$ thick) mainly of aggregate-poor ice containing dispersed silty diamicton, with suspended rounded to subrounded pebbles and cobbles; bands dip apparently at $\sim 6^{\circ}$ towards $210^{\circ}$; laminated subunit ( $\sim 10 \mathrm{~cm}$ thick $)$ at top comprises laminae $\sim 3-7 \mathrm{~mm}$ thick of clear, pure ice and aggregate-poor ice; upper contact sharp, planar to gently undulating, truncating bands; mean $\delta^{18} \mathrm{O}$ value $=-28.1 \%$, std dev. $=$ $0.2 \%, n=6$ (Fig. 7b). An oriented block of ice, examined petrographically, contains sediment grains and clumps suspended in a matrix of fine ice crystals, ice films and pore ice; pebbles coated by ice films $0.3-0.5 \mathrm{~mm}$ thick; ice composed mainly of fine $(0.5-2.0 \mathrm{~mm})$ anhedral crystals; crystal $c$ axes generally display a random pattern (Fig. 2)
Sandy lenses and layers (few millimetres to few metres thick, $\sim 0.15 \mathrm{~m}$ to few tens of metres long), commonly aligned horizontally to subhorizontally

S-shaped folds with horizontal to gently dipping axes within some sand lenses

Ice veins $(\sim 1-2 \mathrm{~mm}$ thick, $\sim 15-60 \mathrm{~cm}$ long) dipping at $20-30^{\circ}$ towards $030^{\circ}$ in basal $0.5 \mathrm{~m}$ of unit

Ice blocks ( $\leq 1 \mathrm{~m}$ long axis, $10-20 \mathrm{~cm}$ short axis), irregular shape, commonly elongate, randomly dispersed (Fig. 8c); commonly aligned parallel or subparallel to sandy lenses and layers; ice facies comprised (1) clear, pure ice; (2) aggregate-poor ice; and (3) ice-rich sand; mean $\delta^{18} \mathrm{O}$ value $=-29.4 \%$, std dev. $=$ $0.8 \%$ o, $n=6$ (Fig. 7b)

Tilted bands
Glacitectonite

Ice lenses (segregated ice) at base post-date deformation

Buried basal ice beneath décollement surface

\footnotetext{
Notes: At site 3b (North Head), a similar, bipartite stratigraphy comprised sand and clay above massive ice (Fig. $8 \mathrm{~d}-\mathrm{f})$; the clay and sand occur as alternating lenses and layers $\sim 2 \mathrm{~mm}$ to $\geq 1 \mathrm{~m}$ thick, and $\sim 2 \mathrm{~cm}$ to $\geq 50 \mathrm{~cm}$ long (Fig. 11), some forming pinch-and-swell structures (Fig. 8d); one pinch-and-swell structure of sand examined in detail is internally subdivided into interdigitating, wavy sand lenses several millimetres to $13 \mathrm{~cm}$ long and $2-22 \mathrm{~mm}$ thick (Fig. 1lb); lenses have pointed ends, and many form miniature pinch-and-swell structures; long axes of lenses are aligned parallel to subparallel to (1) each other, (2) long axis of host pinch-and-swell structure, (3) adjacent sand lenses and layers, (4) axial planes of highly attenuated folds (Fig. 1la), and (5) elongate ice blocks (Fig. 8d); ice blocks have mean $\delta^{18} \mathrm{O}$ value of $-25.5 \%$, std dev. $=2.1(n=12)$; massive ice has $\delta^{18} \mathrm{O}$ values of -31.3 and $32.9 \%$. Fig. 4 ).
} 


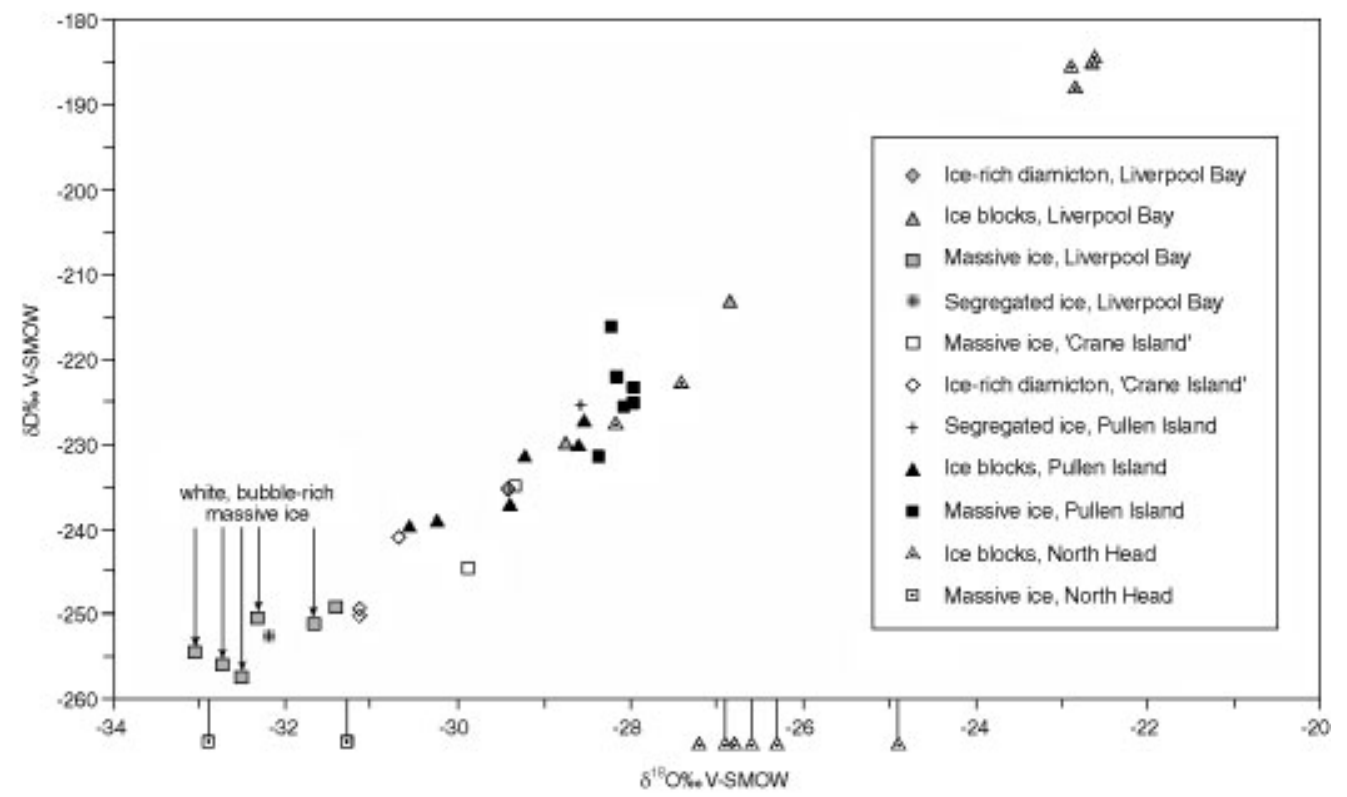

Fig. 4. Co-isotope plot of full dataset for ground ice from Liverpool Bay, 'Crane Island'and Pullen Island. Also shown are oxygen isotope data for massive ice and ice blocks from North Head. The massive ice at all of the sites is of the dark-grey, bubble-poor, banded type, except where white, bubble-rich massive ice is indicated in five of the six samples from Liverpool Bay. V-SMOW: Vienna Standard Mean Ocean Water.

intrasedimental ice) rather than being buried by younger sediment (i.e. buried ice). Intrasedimental massive ice forms in situ by growth of segregated to intrusive ice during downward permafrost aggradation in regions where subpermafrost groundwater is under high pressure (Mackay, 1971; Mackay and Dallimore, 1992). The high pressure may arise from (1) pore-water expulsion during freezing of saturated, coarse-grained sediment such as sand, as occurs during the growth of hydrostatic pingos, but on a larger scale (Mackay, 1971); and/or (2) subglacial meltwater driven towards aggrading permafrost near the edge of an ice sheet in response to a gradient in ice overburden pressure (Rampton, 1988a, b). The pressurized groundwater feeds a lens of massive ice growing at or near the contact of frost-susceptible sediment (e.g. silty clay till) and underlying sand.

Although a buried glacier origin for the white, bubblerich massive ice at Liverpool Bay cannot be discounted, the ice resembles neither contemporary basal nor firnified glacier ice in terms of all its observed field characteristics. Instead, an intrasedimental interpretation is preferred for three reasons: (1) the massive ice isotopically matches segregated ice in the underlying Kittigazuit Formation sand (Fig. 4); (2) the observed lower contact of the massive ice is conformable with this underlying segregated ice; and (3) the massive ice contains layers of suspended sand grains similar to those in the Kittigazuit Formation. All three observations are consistent with downward freezing through the sand. In addition, the ice closely resembles massive intrasedimental ice at Peninsula Point (Fig. 1), both being bubble-rich and relatively sediment-poor (Mackay and Dallimore, 1992). An intrasedimental origin for massive ice directly south of Nicholson Island and therefore in sections near those described here has been proposed independently by French and Harry (1990, fig. 7B).

The origin of the grey, banded massive ice at Liverpool Bay is less certain. Possibly, the ice resulted from shearinginduced regelation along the upper boundary of the white massive ice. This might account for (1) the occurrence of the banded ice directly above the white ice (Fig. 5c); (2) the abundant cracks (shear planes) within the white ice; and (3) the intercalation of debris-rich layers comprising suspended aggregates of sandy silty clay and debris-poor layers, similar to regelation ice in contemporary glaciers (Kamb and LaChapelle, 1964; Hubbard and Sharp, 1995). Alternatively, the intercalation of the white and banded ice types (Fig. 5e) may reflect subsequent folding and shearing during glacial overriding (Hart, 1995; Hart and Waller, 1999).

The debris-rich massive ice at 'Crane Island' and Pullen Island is interpreted as buried basal glacier ice. At 'Crane Island', the sediment dispersed within the bands of aggregate-poor ice is a diamicton visually identical to that in the overlying, ice-rich diamicton, previously mapped as till (Rampton, 1988a). The bands of aggregate-poor ice with suspended rock clasts closely resemble basal stratified suspended sub-facies ice from Matanuska Glacier, Alaska, U.S.A. (Lawson, 1979b), and from the southwest Greenland ice sheet (Knight, 1997; Waller and others, 2000). The clast fabric in the massive ice (Fig. 6c) displays a strongly preferred orientation similar to that characteristic of contemporary basal glacier ice (Lawson, 1979a; Bennett and others, 1999). The massive ice at both 'Crane Island' and Pullen Island lacks the white, bubble-rich ice facies common in massive intrasedimental ice at Liverpool Bay and Peninsula Point.

The oxygen isotope composition of the massive ice at sites $1-3($ mean $=-30.2 \%$, std dev. $=2.0 \%, n=16)$ is similar to that of other massive ice in the Tuktoyaktuk Coastlands (e.g. -28 to $-35 \%$; Mackay, 1983) and to that of Laurentide ice identified at the base of the Barnes Ice Cap, Baffin Island, Canada (mean $=-34.6 \%$; Zdanowicz and others, 2002). The oxygen isotope composition of the massive ice suggests a very cold water source. Refrozen meltwater may be enriched in ${ }^{18} \mathrm{O}$ by as much as $3 \%$, and that would displace intrasedimental massive ice to values more enriched than Laurentide meltwater from, for example, the Barnes Ice Cap. However, the co-isotopic plots for the white, 


\section{a: section 1, western slump}



b: section 1, central slump

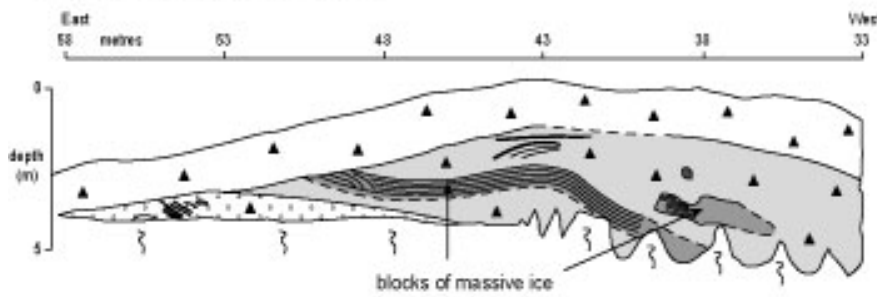

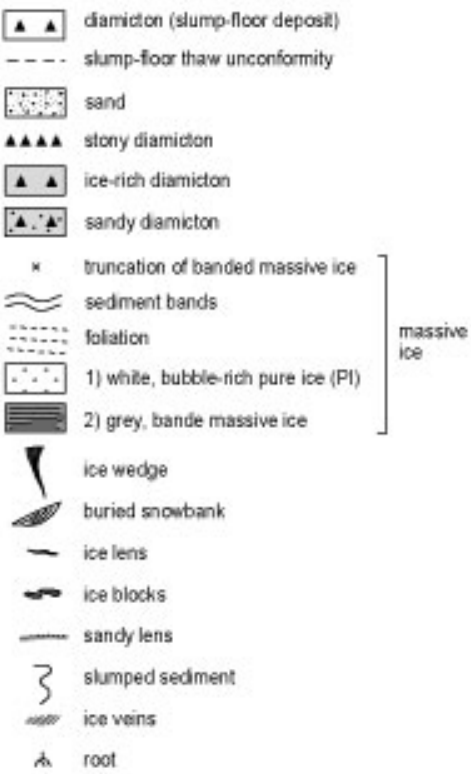

*herex prominent band of irregular reticulate cryostructure

c: section 1, eastern slump

Int 113



d: section 4

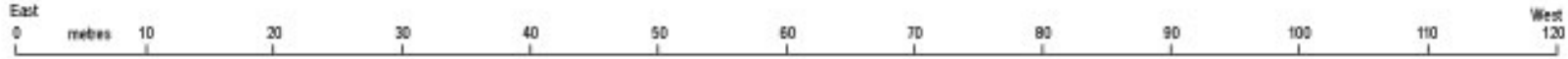

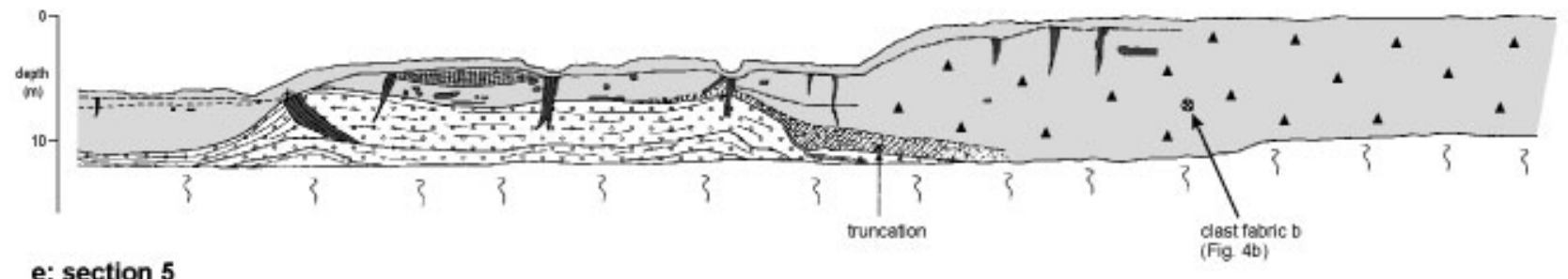

\section{e: section 5}

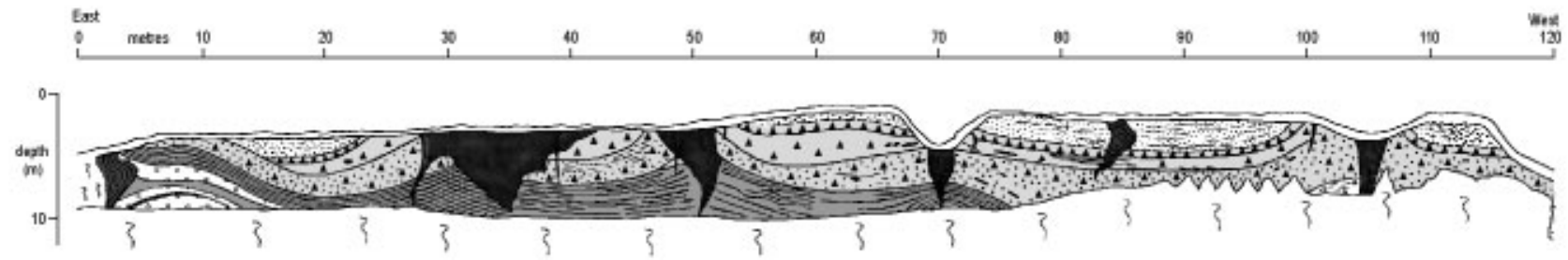

Fig. 5. Stratigraphy at Liverpool Bay. Locations of sections are shown in Figure $3 a$.

bubble-rich massive ice at Liverpool Bay and the banded massive ice at Pullen Island do not assist in the determination of their origin due to their poorly constrained distributions (Fig. 7).

\section{Evidence for subglacial deformation and erosion}

\section{Angular unconformity}

The upper contact of the banded massive ice at all three sites is an angular unconformity resulting from erosion of the ice.
Had the contact formed by downward freezing, we would expect a conformable relationship between the ice and the overlying sediments, i.e. where bands in the massive ice run parallel to the upper contact of the ice (Mackay, 1989, fig. 1). The conformable relationship would reflect alignment of ice and sediment bands orthogonal to the direction of heat flow, a feature characteristic of ice segregation. Alternatively, had the contact formed by downward thaw of the massive ice, the allochthonous blocks of ice (discussed below) in the overlying sediment would have melted. Instead, the contact 
a Ice-rich diamicton, Liverpool Bay



Eigenvalues:

$S_{1}=0.843$

$S_{2}=0.109$

$S_{3}=0.049$

Isothropy $=0.058$

Elongation $=0.871$

Mean vector $=199^{\circ}$

Mean dip $=12^{\circ}$ c Massive ice, 'Crane Island'

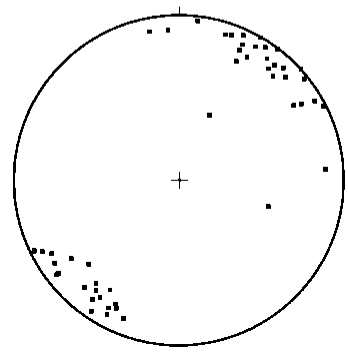

b Ice-rich diamicton, Liverpool Bay

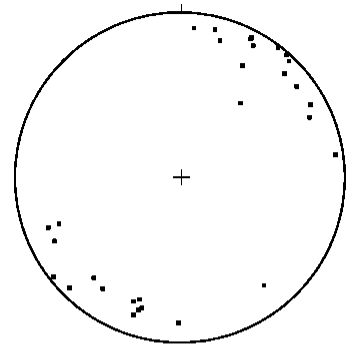

Eigenvalues:

$\mathrm{S}_{1}=0.797$

$S_{2}=0.136$

$\mathrm{S}_{3}=0.067$

Isothropy $=0.829$

Elongation $=0.829$

Mean vector $=216^{\circ}$

Mean $\operatorname{dip}=1^{\circ}$

Fig. 6. Schmidt equal-area stereonets of clast fabrics from ice-rich diamicton at Liverpool Bay (a, b), and massive ice (c) and overlying ice-rich diamicton at 'Crane Island' (d).

is attributed to décollement that truncated the banded massive ice and supplied the ice blocks to the overlying sediment.

\section{Ice blocks (ice clasts)}

The ice blocks are interpreted as ice clasts eroded from preexisting ice. In situ formation of segregated or intrusive ice is discounted where bands within ice blocks are truncated along block margins. Although some ice blocks may conceivably derive from toppling of ice down crevasses or from the ice front, we have not observed blocks of stratified, bubble-rich ice characteristic of firnified glacier ice; but we cannot discount the possibility that small clear ice blocks may be remnants of such ice. More likely, however, is the interpretation that many or all of the ice blocks were eroded from pre-existing ice, particularly massive ice. Erosion from massive ice would account for (1) the large size of some ice blocks ( $\leq 15 \mathrm{~m}$ long $\times \leq 1.5 \mathrm{~m}$ high; Figs $5 \mathrm{a}$ and $8 \mathrm{~b}$ ); (2) the similarity of ice facies in many blocks to those in the banded massive ice; (3) the stratigraphic occurrence of ice blocks above or laterally adjacent to massive ice; (4) the angular unconformity (erosion surface) along the top of the massive ice; and (5) those ice blocks with $\delta^{18} \mathrm{O}$ values of -28 to $-30 \%$, which are within the $\delta^{18} \mathrm{O}$ range obtained from massive ice in the present study ( -28.0 to $-33.1 \%$; Fig. 4) and by Mackay (1983). In addition, the similar size, shape and alignment of many ice blocks to adjacent sand lenses derived from pre-existing sand, as discussed below, are consistent with subglacial erosion and deformation.

Those ice blocks from North Head with $\delta^{18} \mathrm{O}$ values of $-22 \%$ are isotopically too heavy to derive from massive ice. They are also too heavy to derive from single-stage refreezing of meltwater from massive ice, which could produce $\delta^{18} \mathrm{O}$ values no heavier than about $-25 \%$, and may account for ice blocks with intermediate $\delta^{18} \mathrm{O}$ values of $\sim-27$ to $-25 \%$ (Fig. 4). Instead, the ice blocks with $\delta^{18} \mathrm{O}$ values of $-22 \%$ may derive from a different climate regime because shifts of $5-10 \%$ or for $\delta^{18} \mathrm{O}$ usually correspond with glacialto-interglacial or stadial-to-interstadial changes. Hence, the isotopically heaviest ice blocks may be fragments of preglacial ground ice dating from a warm climatic period. Another process that will enrich the ice is the contribution of ambient precipitation, which falls at lower elevation than in the higher catchments of the LIS and is likely summerdominated off the Beaufort Sea.

The alignment of elongate ice blocks more or less parallel to adjacent sand lenses and laminae, and the smooth deflection of some sand lenses around them are attributed to movement within a shear zone. The rounded and streamlined shape of many ice blocks may reflect partial melting and/or erosion within the shear zone.

Folds within ice blocks developed either before or during movement within the shear zone. The unusual truncated fold shown in Figure 8a was probably eroded from a fold similar to those common in the banded massive ice at Liverpool Bay. If such folding developed after blocks were eroded, we would expect to observe many more examples of ice blocks containing similar folds.

\section{Glacitectonite}

The ice-rich diamicton at Liverpool Bay and 'Crane Island' (see Fig. 9) and the sandy silt at Pullen Island (see Fig. 10) are interpreted as glacitectonite. An origin as till is discounted because these frozen sediments contain ice clasts and do not overlie a thaw unconformity; hence the sediment has never melted out and been finally deposited (cf. Kaplyanskaya and Tarnogradskiy, 1986; Dyke and Savelle, 2000). Instead, an origin as glacitectonite is consistent with (1) the evidence for a lack of thaw, (2) the occurrence of striated and/or faceted rock clasts at 'Crane Island', and (3) the inclusions of sand or ice blocks. The brown, fine sand in some sand lenses and layers at Liverpool Bay has clearly been eroded from the underlying, preglacial Kittigazuit Formation. The streamlined shape to some sand lenses, similar to augen and boudins in metamorphic rocks (Passchier and Trouw, 1996), is attributed to erosion and deformation of the edges of stiff sand pods during shear within more rapidly deforming finer-grained sediment in the surrounding 



Fig. 7. Co-isotope plots showing regression lines for (a) massive ice at Liverpool Bay, and (b) massive ice and ice blocks at Pullen Island.

diamicton. Similar lenses and laminations have been reported in subglacially deformed Pleistocene sediments in Canada (Menzies, 1990) and the U.K. (Hart and Boulton, 1991; Benn and Evans, 1996).

The sites display a variety of structures commonly observed within subglacially deformed sequences. Recumbent folds are present at all sites and indicate simple shear and ductile deformation, forming where there is a perturbation in the junction between two layers of differing rheology. As strain increases, the fold becomes more attenuated in the direction of principal shear, producing a tectonic lamination. Figure 1la shows various stages in the attenuation of inhomogeneities into fold noses and allochthonous folds. The pinch-and-swell structures at North Head reflect horizontal extension parallel to layering and brittle failure of the sand layer within a more ductile matrix. Their incomplete separation suggests only a slight difference in competency between the two units (Roberts, 1989). The small sand lenses observed within one such pinch-and-swell structure (Fig. 1lb) are interpreted as shear lenses, similar to those reported from the Bl horizon of subglacially deformed, unfrozen sediment from Svalbard (Boulton, 1970) and Iceland (Boulton, 1987). Additional evidence for brittle failure is provided by (l) ice veins within the ice-rich diamicton and (2) cracks within the white, bubbly massive ice at Liverpool Bay. The ice veins probably mark tension cracks formed in a shear zone. Similar features, often comprising quartz or calcite veins and interpreted as en échelon tension gashes, define brittle shear zones in rock (cf. Roberts, 1989). In the case of the structures reported here, fracturing is inferred during shear, with segregated ice infilling the fractures during or after shear.

Clast fabrics are commonly used to reconstruct the strain history of sheared materials, and have been applied both to sediment-rich basal glacier ice (e.g. Lawson, 1979a; Ham and Mickelson, 1994; Bennett and others, 1999) and to subglacial sediments (Hart, 1994; Benn, 1995; Bennett and others, 1999). As the ice-rich diamictons have been deformed in a frozen state, comparisons with the former are more appropriate. Both Lawson (1979a) and Ham and Mickelson (1994) suggest that sediment-rich basal glacier ice is characterized by very strong, flow-parallel fabrics with $S_{1}$ values mostly $>0.8$; they group tightly near the cluster apex of triangular eigenvalue plots (Benn, 1994). Although the fabrics recorded from ice-rich diamicton at Liverpool Bay display similar strengths $\left(S_{1}=0.843\right.$ and 0.797$)$, consistent with their interpretation as a glacially deformed ice-sediment mixture, the sample from 'Crane Island' displays a much weaker orientation $\left(S_{1}=0.605\right)$. Although this result falls outside the range of data for basal ice presented by Lawson (1979a) and Ham and Mickelson (1994), it does lie within the range of values presented by Bennett and others (1999) and therefore is consistent with a glacially deformed ice--sediment mixture. The mean vectors from the ice-rich diamicton and massive ice (Fig. 6) are all approximately parallel to the ice-flow direction independently inferred by Rampton (1988a) (Fig. 1).

The range of oxygen isotope values obtained from reticulate ice within the ice-rich diamicton at Liverpool Bay and 'Crane Island' (-29.4 to $-31.2 \%$ ) is within the range typical of massive ice in the Tuktoyaktuk Coastlands, and indicates a very cold water source. This discounts thaw of the ice-rich diamicton during the Holocene and mixing with isotopically heavier water from warmer climatic conditions.

\section{Postglacial processes}

\section{Ice segregation}

The large ice lenses in the ice-rich diamicton at Liverpool Bay and the silty sand at Pullen Island formed by ice segregation after glacial deformation had ceased. If the ice lenses pre-dated deformation, we would expect them to have been boudinaged or eroded, to form ice clasts. At Liverpool Bay the location of the ice lenses within or directly above sand lenses was clearly influenced by the orientation of sand-diamicton contacts, i.e. between frost-susceptible and nonfrost-susceptible sediment. The $\delta^{18} \mathrm{O}$ values of the segregated ice at both sites (Fig. 7) suggest a very cold water source, and discount mixing with isotopically heavier water associated with warmer climatic conditions during the Holocene.

\section{Active-layer deepening and mass movement}

The ice-rich silt at 'Crane Island' is interpreted as Holocene colluvium, consistent with burial of organic matter by downslope soil movement. The sharp base of the silt is a thaw unconformity that probably marks the base of the early-Holocene active layer, when the active layer was regionally deeper than at present, melting the tops of the buried ice wedges (Fig. 9; cf. Mackay, 1975; Burn, 1997). 



Fig. 8. Ice blocks (ice clasts) in near-surface permafrost. (a) Ice blocks within ice-rich diamicton, Liverpool Bay, 8 July 1998. One block comprises the hinge of a truncated fold. Spade for scale. (b) Block of massive ice ( $\sim 15 \mathrm{~m}$ long) within ice-rich diamicton, Liverpool Bay, 8 July 1998; location shown in Figure 5a. (c) Chaotic arrangement of ice blocks (arrows) in sandy silt unit, Pullen Island, 4 May 1999. Person with ice axe for scale. (d) Elongate ice blocks aligned parallel to glaciotectonic lenses and pinch-and-swell structures of sand and clay, North Head, 10 August 1991. Trowel for scale. (e) Large ice block showing truncated bands along its sides, North Head, 10 August 1993. Spade for scale. (f) Excavated ice block with streamlined form, North Head, 11 August 1993.

\section{DISGUSSION}

Our observations allow us to make some important inferences about deformation, rheology and erosion of permafrost beneath the cold-based margin of a former ice sheet.

Glaciotectonic deformation at sites 1-3 occurred beneath the margin of the LIS. Proglacial deformation is discounted because the glaciotectonic structures described, in particular the isoclinal recumbent folds and pinch-andswell structures, indicate simple shear and extension, which are characteristic of subglacial deformation, as discussed above, rather than compressive strains associated with proglacial deformation (cf. Hart and Boulton, 1991). In addition, the ice clasts resemble in size and shape sediment inclusions characteristic of subglacially deformed sediment (e.g. Benn and Evans, 1996), and it is difficult to understand how they could have been eroded proglacially. However, subglacial deformation beneath the warm-based interior of the ice sheet is discounted because the glacitectonite has never thawed. Instead, deformation took place beneath the cold-based margin of the LIS. The possibility that glacier overriding was preceded or followed by proglacial deformation cannot be excluded.
Deformation occurred while the sediment was frozen but contained limited amounts of liquid water. Pervasive unfrozen conditions during deformation are precluded because (1) massive ice and (2) eroded and deformed ice blocks interpreted as ice clasts are preserved within the deformed permafrost. However, the glacitectonite must have contained some liquid water, because segregated ice could not otherwise have formed within it after deformation had ceased. The unfrozen water probably resulted from freezing-point depression in clay-rich sediments such as the icerich diamicton and/or from local pressure melting during deformation, for example, at the top of the white massive ice at Liverpool Bay. It is well documented in the permafrost literature that ice and unfrozen water can coexist, and that ice segregation can occur in fine-grained frozen soils at temperatures of a few degrees below $0^{\circ} \mathrm{C}$ (Williams and Smith, 1989).

The presence and quantity of liquid water are key determinants of the mechanical properties of frozen ground. Liquid water reduces the strength of both ice-ice and icesediment bonds and, in the case of ice--sediment mixtures, substantially reduces cohesion (Williams and Smith, 1989). In addition to temperature, the amount of liquid water 


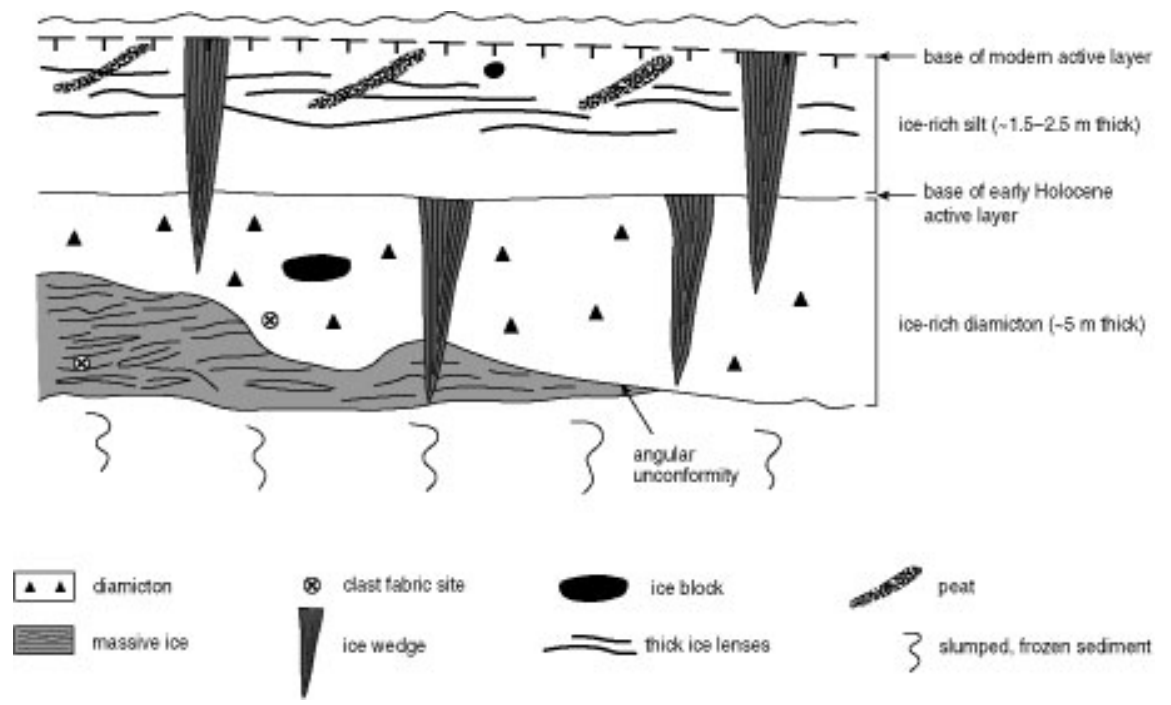

Fig. 9. Schematic stratigraphy at 'Crane Island'.

present strongly depends on grain-size, with clay retaining significant quantities down to temperatures well below the freezing point. Frozen, fine-grained sediments thus display much lower yield stresses than frozen coarse-grained sediments, and at temperatures between $0^{\circ} \mathrm{C}$ and $-2^{\circ} \mathrm{C}$ are more susceptible to creep deformation than is pure ice (Johnston and others, 1981). These experimental results concerning variations in unfrozen water content provide a theoretical explanation for the competency contrasts inferred from the permafrost stratigraphy at sites 1-3: the ice clasts and layers and lenses of frozen sand constituted relatively competent units within a more rapidly deforming shear zone of partially frozen, ice-rich diamicton. Such warm conditions (i.e. close to the pressure-melting point) result in a reduction in the yield stress of both the ice and frozen sediment and thereby promote pervasive creep deformation (Vialov, 1965; Mellor and Testa, 1969). Tsytovich (1975) terms this type of easily deformable permafrost 'plastic-frozen ground', as opposed to 'hard-frozen ground', which is comparatively rigid.

Rheologically, the deformed permafrost is dominated by structures indicative of ductile or creep deformation, includ-

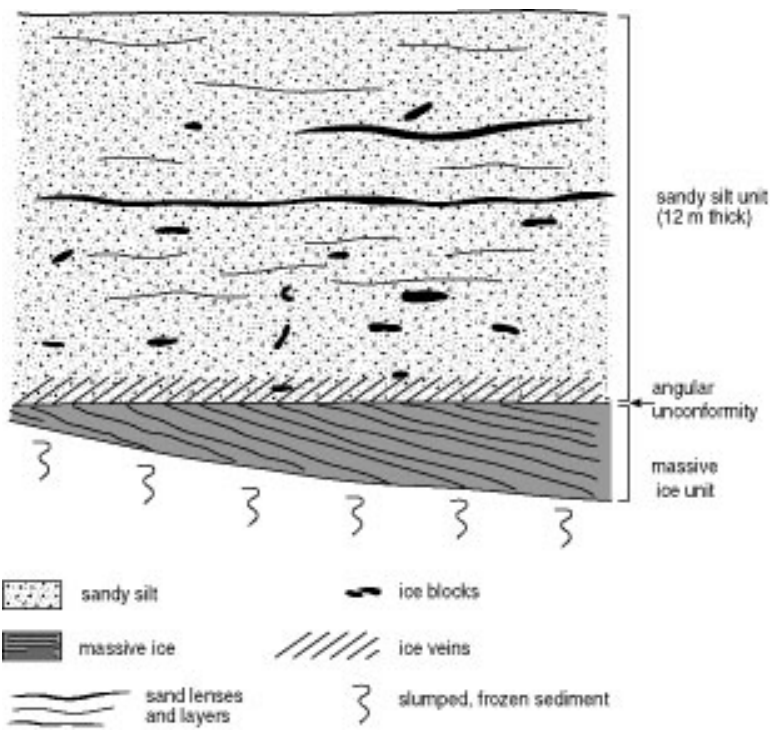

Fig. 10. Schematic stratigraphy at Pullen Island. ing a variety of fold types (recumbent and S-shaped). This style of deformation is common in relatively warm, ice-rich materials subjected to low deviatoric stresses over long time periods. There is, however, evidence for brittle failure in the form of pinch-and-swell structures at North Head and en échelon tension gashes at Liverpool Bay and Pullen Island. The tension gashes may have resulted from variations in the strain rate (personal communication from G. D. Williams, 2003) and/or temperature within the deforming permafrost. Alternatively, they may reflect local extension and the tendency of ice to fail in a brittle fashion when subjected to tensile stress (Williams and Smith, 1989). The clast-fabric data, featuring a range of weak and strongly orientated fabrics, may also indicate the occurrence of both pervasive, ductile deformation and brittle or brittle/ductile shear (Hart, 1994; Benn, 1995).

Erosion of permafrost accompanied deformation. Erosion is indicated by (1) the angular unconformity along the top of the massive ice and (2) the abundant ice clasts within the overlying glacitectonite. The unconformity marks a décollement surface beneath a shear zone. At Liverpool Bay and 'Crane Island' this surface was irregular (Figs 5 and 9), but at Pullen Island it was subhorizontal (Fig. 10). The nature of this contact is consistent with erosion of pre-existing irregularities in the ice, as discussed by Boulton (1987) in the case of subglacial deformation of unfrozen sediment. Shear at this contact may also have promoted regelation and deformation within the underlying massive ice and the formation of the banded ice facies at Liverpool Bay.

A schematic model of permafrost deformation beneath the northwest margin of the LIS is shown in Figure 12. The model is broadly consistent with that inferred by Astakhov and others (1996) in western Siberia, because both models involve (1) subglacial extension over a weak zone of finegrained and/or ice-rich permafrost, and (2) significant subglacial erosion of frozen materials. The model also supports Mathews and Mackay's (1960) suggestion that glacialinduced shearing may occur in clayey beds in permafrost. However, our observations, which are confined to near-surface permafrost, do not allow testing of Mathews and Mackay's (1960) inference that high pore-water pressures beneath subglacial permafrost facilitated glacial thrusting by reducing the shear strength of unfrozen soil. 

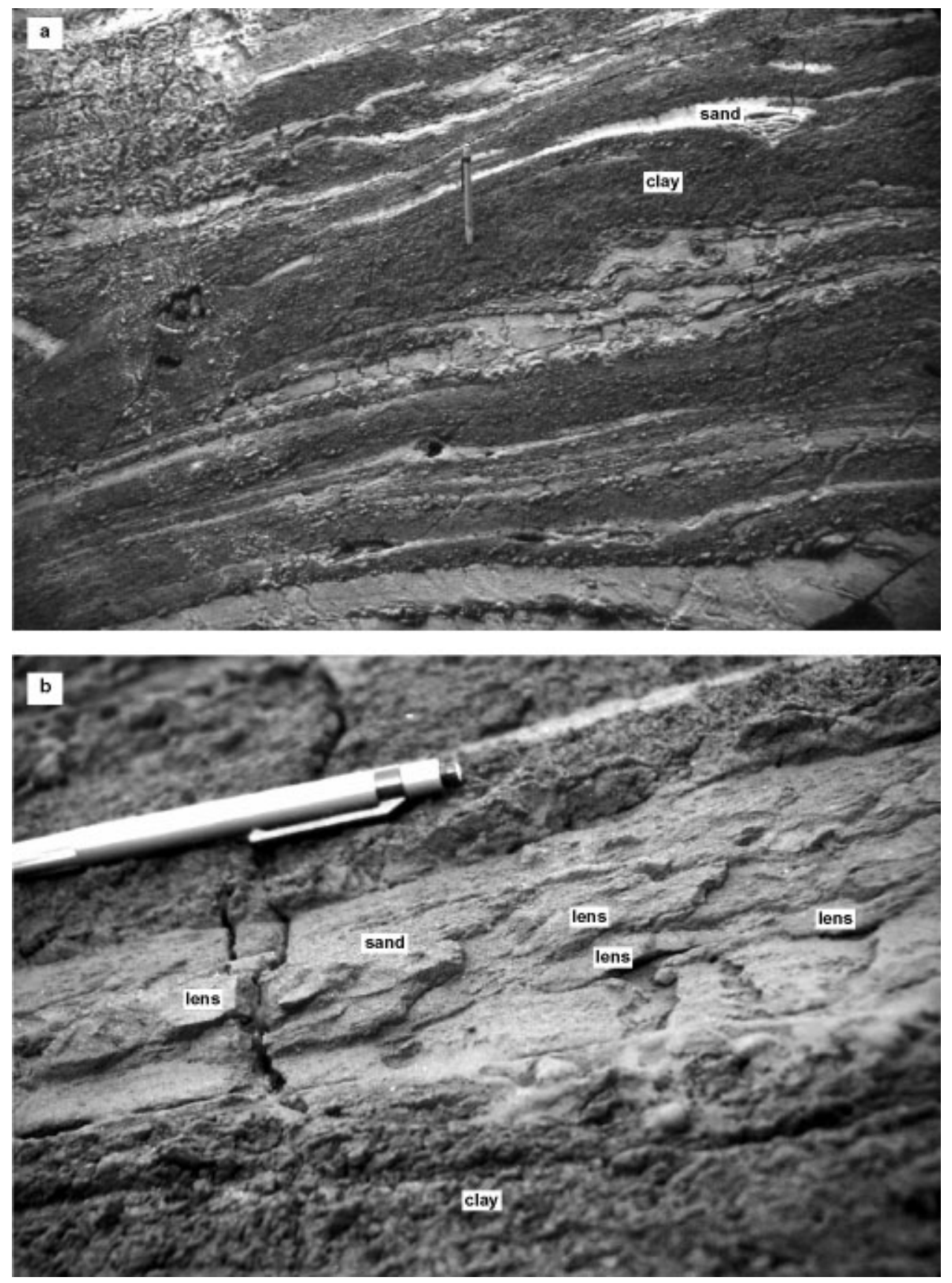

Fig. 11. Glacitectonite at North Head. (a) Lenses and layers of sand within silty clay. Note the various stages of attenuation of inhomogeneities into fold noses and allochthonous folds. Pencil for scale. (b) Close-up of lenses within a pinch-and-swell structure of sand. Pencil for scale.

\section{CONGLUSIONS}

The main conclusions from this study are as follows:

(1) Ice-rich permafrost in the Tuktoyaktuk Coastlands was deformed to depths of at least 5-20 m beneath the northwest margin of the LIS. The deformed permafrost examined comprised frozen glacitectonite above intrasedimental massive ice or buried basal glacier ice. Because this mixture of ice and sediment moved subglacially, the deformed permafrost could be considered to represent either a frozen subglacial deforming layer or a debris-rich basal ice layer.

(2) Rheologically, the deformed permafrost is dominated by glaciotectonic structures (recumbent and S-shaped folds, sand lenses and layers) indicative of ductile deformation and common in warm, ice-rich materials.
The ice clasts and sand layers and lenses within the glacitectonite constituted relatively competent, frozen units within a more rapidly deforming shear zone of finer sediment that contained both ice and limited amounts of liquid water.

(3) Subglacial erosion of permafrost formed an angular unconformity along the top of the massive ice, and supplied frozen Pleistocene sediment and ice clasts to the glacitectonite. The ice clasts were eroded from pre-existing ground ice.

(4) Two types of ground ice occur in the deformed permafrost: (i) massive ice and ice clasts, both of which have been glacially deformed, eroded or moved; and (ii) segregated ice and ice-wedge ice that have not been glacially disturbed because they post-date deformation. 


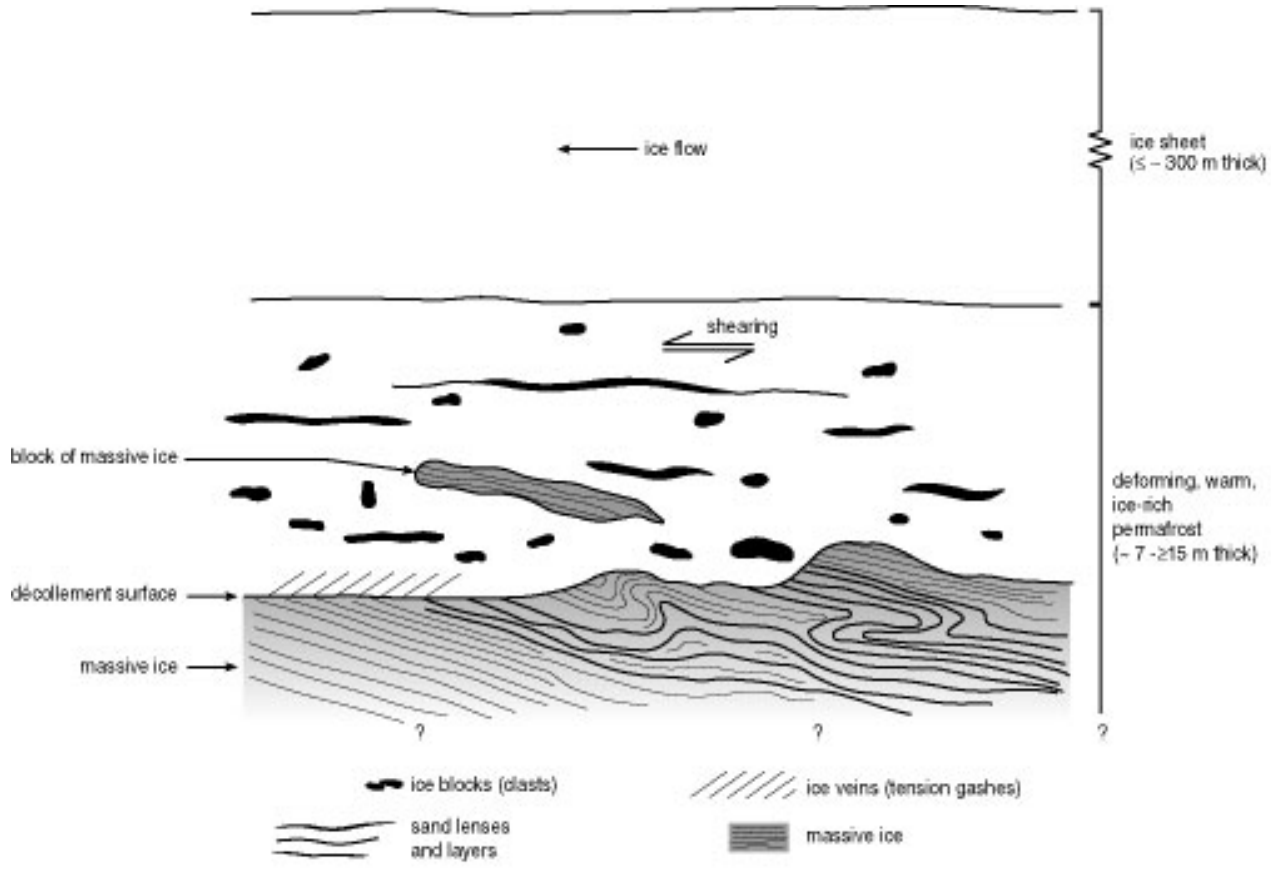

Fig. 12. Schematic model of deforming, warm, ice-rich permafrost beneath the northwest margin of the LIS. The approximate thickness of the ice sheet is based on Rampton's (1988a) reconstruction.

\section{ACKNOWLEDGEMENTS}

J.B.M.s fieldwork between 1989 and 1993 was supported by grants (to Professor H. M. French) from the Natural Sciences and Engineering Research Council, Canada, and the Geological Survey of Canada (GSG). Logistical support was provided by the Polar Continental Shelf Project, Natural Resources Canada; the GSC; and the Inuvik Research Centre, Aurora College. Fieldwork in 1998 and 1999 was funded by grants (to J.B.M.) from the Leverhulme Trust and the Tyrell Fund of the Geological Society. R.I.W.'s participation was supported by the University of Greenwich. C.A.W. was supported by the University of Brighton Research Support Fund. A. D. Green, B. P. Lowe and F. Wolki assisted with fieldwork. S. Rowland and H. Lintott produced the figures. D. J. A. Evans and an anonymous referee are thanked for their constructive comments on the paper. This is Polar Continental Shelf Project contribution No. 02403.

\section{REFERENGES}

Astakhov, V. I., F. A. Kaplyanskaya and V. D. Tarnogradskiy. 1996. Pleistocene permafrost of west Siberia as a deformable glacier bed. Permafrost and Periglacial Processes, 7(2), 165-191.

Beget, J. 1987. Low profile of the northwest Laurentide Ice Sheet. Arct. Alp. Res., 19(1), 81-88.

Benn, D. I. 1994. Fabric shape and the interpretation of sedimentary fabric data. 7. Sediment. Res., Ser. A, 64(4), 910-915.

Benn, D. I. 1995. Fabric signature of subglacial till deformation, Breiðamerkurjökull, Iceland. Sedimentology, 42(5), 735-747.

Benn, D. I. and D. J. A. Evans. 1996. The interpretation and classification of subglacially-deformed materials. Quat. Sci. Rev., 15(1), 23-52.

Bennett, M. R., R. I. Waller, N. F. Glasser, M. J. Hambrey and D. Huddart. 1999. Glacigenic clast fabrics: genetic fingerprint or wishful thinking? 7. Quat. Sci., 14(2), 125-135.

Boulton, G. S. 1970. On the deposition of subglacial and melt-out tills at the margins of certain Svalbard glaciers. f. Glaciol., 9(56), 231-245.

Boulton, G. S. 1987. A theory of drumlin formation by subglacial sediment deformation. In Menzies, J. and J. Rose, eds. Drumlin Symposium. Rotterdam, A. A. Balkema, 25-80.
Burn, C. R. 1997. Cryostratigraphy, paleogeography and climate change during the early Holocene warm interval, western Arctic coast, Canada. Can. 7. Earth Sci., 34(7), 912-935.

Cutler, P. M., D. R. MacAyeal, D. M. Mickelson, B. R. Parizek and P. M. Colgan. 2000. A numerical investigation of ice-lobe--permafrost interaction around the southern Laurentide ice sheet. f. Glaciol., 46(153), 311-325.

Dallimore, S. R. and S. A. Wolfe. 1988. Massive ground ice associated with glaciofluvial sediments, Richards Islands, N.W.T., Canada. In Senneset, K., ed. Permafrost. Fifth International Conference. Proceedings. Vol. 1. August 2-5, 1988. Trondheim, Tapir Publishers, 132-137.

Dallimore, S. R., S. A. Wolfe, J. V. Matthews, Jr and J.-S. Vincent. 1997. MidWisconsinan eolian deposits of the Kittigazuit formation, Tuktoyaktuk Coastlands, Northwest Territories, Canada. Can. 7. Earth Sci., 34(11), 1421-1441.

Dyke, A. S. and J. M. Savelle. 2000. Major end moraines of Younger Dryas age on Wollaston Peninsula,Victoria Island, Canadian Arctic: implications for paleoclimate and for formation of hummocky moraine. Can. $\mathcal{F}$. Earth Sci., 37(4), 601-619.

French, H. M. and D. G. Harry. 1990. Observations on buried glacier ice and massive segregated ice, western Arctic coast, Canada. Permafrost and Periglacial Processes, 1(1), 31-43.

Ham, N. R. and D. M. Mickelson. 1994. Basal till fabric and deposition at Burroughs Glacier, Glacier Bay, Alaska. Geol. Soc. Am. Bull., 106(12), $1552-1559$.

Hart, J. K. 1994. Till fabric associated with deformable beds. Earth Surf. Processes Landforms, $\mathbf{1 9}$ (1), 15-32.

Hart, J. K. 1995. An investigation of the deforming layer/debris-rich basal ice continuum, illustrated from three Alaskan glaciers. F. Glaciol., $41(139), 619-633$.

Hart, J. K. and G. S. Boulton. 1991. The interrelation of glaciotectonic and glaciodepositional processes within the glacial environment. Quat. Sci. Rev., 10(4), 335-350.

Hart, J. K. and R. I. Waller. 1999. An investigation of the debris-rich basal ice from Worthington Glacier, Alaska, U.S.A. F. Glaciol., 45(149), 54-62.

Hubbard, B. and M. Sharp. 1995. Basal ice facies and their formation in the western Alps. Arct. Alp. Res., 27 (4), 301-310.

Johnston, G. H., B. Ladanyi, N. R. Morgenstern and E. Penner. 1981. Engineering characteristics of frozen and thawing soils. In Johnston, G. H., ed. Permafrost: engineering design and construction. New York, etc., John Wiley and Sons, 73-147.

Judge, A. S., B. R. Pelletier and I. Norquay. 1987. Permafrost base and distribution of gas hydrates. Geol. Surv. Can. Misc. Rep. 40, 39.

Kamb, B. and E. LaChapelle. 1964. Direct observation of the mechanism of glacier sliding over bedrock. F. Glaciol., 5(38), 159-172. 
Kaplyanskaya, F. A. and V. D. Tarnogradskiy. 1986. Remnants of the Pleistocene ice sheets in the permafrost zone as an object for paleoglaciological research. Polar Geogr. Geol., 10, 257-266.

Knight, P. G. 1997. The basal ice layer of glaciers and ice sheets. Quat. Sci. Rev., 16(9), 975-993.

Langway, C. C., Jr. 1958. Ice fabrics and the universal stage. SIPRE Tech. Rep. 62.

Lawson, D. E. 1979a. A comparison of the pebble orientations in ice and deposits of the Matanuska Glacier, Alaska. F. Geol., 87(6), 629-645.

Lawson, D. E. 1979b. Sedimentological analysis of the western terminus region of the Matanuska Glacier, Alaska. CRREL Rep. 79-9.

Mackay, J. R. 1971. The origin of massive icy beds in permafrost, western Arctic coast, Canada. Can. 7. Earth Sci., 8 (4), 397-422.

Mackay, J. R. 1975. Relict ice wedges, Pelly Island, N.W.T. Geol. Surv. Can. Pap. 75-1A, 469-470.

Mackay, J. R. 1983. Oxygen isotope variations in permafrost, Tuktoyaktuk Peninsula area, Northwest Territories. Geol. Surv. Can. Pap. 83-1B, 67-74.

Mackay, J. R. 1989. Massive ice: some field criteria for the identification of ice types. Geol. Surv. Can. Pap. 89-1G, 5-11.

Mackay, J. R. and S. R. Dallimore. 1992. Massive ice of the Tuktoyaktuk area, western Arctic coast, Canada. Can. 7. Earth Sci., 29(6), 1235-1249.

Mackay, J. R., V. N. Rampton and J. G. Fyles. 1972. Relic Pleistocene permafrost, western Arctic, Canada. Science, 176(4041), 1321-1323.

Mark, D. M. 1973. Analysis of axial orientation data, including till fabrics. Geol. Soc. Am. Bull., 84(4), 1369-1373.

Mathews, W. H. and J. R. Mackay. 1960. Deformation of soils by glacier ice and the influence of pore pressures and permafrost. Transactions of the Royal Society of Canada, Ser. 3, 59, 27-36.

Mellor, M. and R. Testa. 1969. Effect of temperature on the creep of ice. f. Glaciol., 8(52), 131-145.

Menzies, J. 1990. Sand intraclasts within a diamicton mélange, southern Niagara Peninsula, Ontario, Canada. F. Quat. Sci., 5(3), 189-206.

Murton, J. B. and H. M. French. 1994. Cryostructures in permafrost, Tuktoyaktuk Coastlands, western Arctic Canada. Can. 7. Earth Sci., 31(4), $737-747$.

Murton, J. B., H. M. French and M. Lamothe. 1997. Late Wisconsinan erosion and aeolian deposition, Summer and Hadwen Islands, MacKenzie Delta area, western Canadian Arctic: optical dating and implications for glacial chronology. Can. J. Earth Sci., 34(2), 190-199.
Murton, J. B., C. A. Whiteman, R. I. Waller, W. H. Pollard, I. D. Clark and S. R. Dallimore. In press. Basal ice facies and supraglacial melt-out till of the Laurentinde Ice Sheet, Tuktoyaktuk Coastlands, western Arctic Canada. Quat. Sci. Rev.

Passchier, C.W. and R. A. J. Trouw. 1996. Microtectonics. Berlin and Heidelberg, Springer-Verlag.

Pollard, W. H. 1990. The nature and origin of ground ice in the Herschel Island area, Yukon Territory. Université Laval. Centre d'Études Nordiques. Collection Nordicana, 54, 23-30.

Rampton, V. N. 1982. Quaternary geology of the Yukon Coastal Plain. Geol. Surv. Can. Bull. 317.

Rampton, V. N. 1988a. Origin of massive ground ice on Tuktoyaktuk Peninsula, Northwest Territories, Canada: a review of stratigraphic and geomorphic evidence. In Senneset, K., ed. Permafrost. Fifth International Conference.Vol. 1. August 2-5, 1988. Trondheim, Tapir Publishers, 850-855.

Rampton, V. N. 1988b. Quaternary geology of the Tuktoyaktuk Coastlands, Northwest Territories. Geol. Surv. Can. Mem. 423.

Roberts, J. L. 1989. The Macmillan field guide to geological structures. London, Macmillan Press.

Taylor, A. E., S. R. Dallimore and A. S. Judge. 1996. Late Quaternary history of the Mackenzie-Beaufort region, Arctic Canada, from modelling of permafrost temperatures. 2. The Mackenzie Delta - Tuktoyaktuk Coastlands. Can. 7. Earth Sci., 33(1), 62-71.

Tsytovich, N. A. 1975. The mechanics of frozen ground [Mekhanika merzlykh gruntov7. Washington, DC, Scripta Book Co.

Vialov, S. S. 1965. The strength and creep of frozen soils and calculations for ice-soil retaining structures. Translation 76 edition. Hanover, NH, U. S. Army Cold Regions Research and Engineering Laboratory.

Vincent, J.-S. 1992. The Sangamonian and Early Wisconsinan glacial record in the western Canadian Arctic. In Clark, P. U. and P. D. Lea, eds. The last interglacial-glacial transition in North America. Boulder, CO, Geological Society of America, 233-252. (GSA Special Paper 270.)

Waller, R. I., J. K. Hart and P. G. Knight. 2000. The influence of tectonic deformation on facies variability in stratified debris-rich basal ice. Quat. Sci. Rev., 19 (8), 775-786.

Williams, P. J. and M.W. Smith. 1989. The frozen Earth: fundamentals of geocryology. Cambridge, Cambridge University Press.

Zdanowicz, C. M., D. A. Fisher, I. Clarke and D. Lacelle. 2002. An icemarginal $\delta^{18} \mathrm{O}$ record from Barnes Ice Cap, Bafin Island, Canada. Ann. Glaciol., 35, 145-149. 